REPORT

\title{
Should infection still be considered as the most likely triggering factor for rheumatoid arthritis?*
}

\author{
S M Carty, N Snowden, A J Silman
}

Ann Rheum Dis 2004;63(Suppl II):ii46-ii49

$\Delta$ lthough genetic factors are important in the development of rheumatoid arthritis (RA), not all those who are genetically susceptible develop the disease. Twin studies in the United Kingdom and Australia have shown disease concordance rates in monozygotic twins of between 15 to $21 \% .^{12}$ Earlier studies also showed only modest concordance for autoantibody and immunoglobulin production within twin pairs. ${ }^{3}{ }^{4}$ There is weak evidence, however, of an increased concordance of RA, rheumatoid factor, and other autoantibodies within spouse pairs. ${ }^{5}$ These observations have encouraged the search for environmental triggers, such as infection. In this issue of The Journal [The Journal of Rheumatology], for example, a report from Finland has highlighted the high prevalence of prior infection in patients newly presenting with all forms of inflammatory arthritis. ${ }^{6}$

Evidence that infection is the likeliest environmental trigger for RA is considered in this review: First, we look at the different ways in which infection might act as an etiological agent in RA. We then discuss whether the descriptive epidemiology of RA is consistent with an infective trigger. In conclusion, we review evidence that various specific infections play a role in the causation of the disease.

Historically, demonstrating that an infectious agent plays a key role in disease has required the fulfilment of Koch's postulates. These derive from a model of infectious disease whereby the etiological organism has a direct and continuing role in pathogenesis. However, the relationship between infection and a disease such as RA may be more subtle and complex, and different types of experimental design and evidence may therefore be required to confirm any given organism's role in the disease. Koch's postulates have recently been reformulated to define the criteria that need to be fulfilled to determine whether an organism might have an etiological role in RA. ${ }^{7}$ It is important therefore to consider the various ways in which infection might be associated with RA:

(1) Nature of the organism: Is the putative trigger a novel organism or a previously described, well characterized entity?

(2) Uniqueness: Should the search focus on one agent or could there be multiple triggers?

(3) Attack rate: Is the triggering infection a common (or even ubiquitous) organism that is idiosyncratically handled, leading to RA in a minority, or an agent that leads to RA in most of those affected?

(4) Delay: Is the interval between infection and disease short or perhaps many years long?

(5) Persistence: Is a triggering organism present in active replicating form in RA synovium, playing a role in perpetuation of the disease or acting as a trigger for autoimmunity (perhaps by molecular mimicry), the organism being undetectable in established disease?
(6) Site: Is the triggering infection sited in the synovium, or at a distant site (rheumatic fever or reactive arthritis being examples of how distant infection may trigger joint disease)?

Recent secular trends in the epidemiology of RA are consistent with a role for infection as a susceptibility factor, although many other explanations are possible. Historically, it has been suggested that in developed countries RA is a disease of recent onset. ${ }^{8}$ Skeletal remains from North American populations suggest that the disease was present over 4000 years ago. ${ }^{9}$ The hypothesis was posed that onset of $\mathrm{RA}$ is related to transmission of a relevant infection from the native population of the Old World to the colonizers. ${ }^{9}$ RA is declining in incidence, ${ }^{10}$ with recent, fairly dramatic, falls in disease occurrence in populations thought to be genetically predisposed, such as the Pima Indians, ${ }^{11}$ as well as those of North Americans of European origin. ${ }^{12}$ Although this may reflect changes in many environmental factors, falling rates of infection are a plausible explanation. There is also a suggestion of a birth cohort effect, with evidence of declining incidence with successively recent birth cohorts. Consistent with this are data suggesting a shift towards an old age at peak onset. ${ }^{13}$ Such an effect would be consistent with a decline in infection in early life, which reduces the risk in such a group as they age.

If infection was an important trigger, it might be expected that RA would be more frequent in situations where transmission of an infectious agent was more likely, and the epidemiology of RA would display patterns in time and space typical of an infectious disease. Surrogate markers of infection might include spatial and temporal clustering, poor social conditions, ${ }^{14}$ family size, and factors such as contact with animals or other biological hazards. No consistent pattern emerges from this type of study. Geographical clustering is a common feature of infectious disease, and provided early evidence that Lyme disease was due to infection. ${ }^{15}$ However, although clustering has been described in $\mathrm{RA}^{16}{ }^{16}$ the vast majority of cases occur sporadically. ${ }^{17}$ There is also no evidence that overcrowding per se is associated with an increased risk of onset. ${ }^{18}$ RA may occur more frequently in those from a large sibship, although this is not a consistent finding. ${ }^{19}$ Pet ownership is more likely prior to the onset of $\mathrm{RA}^{20}$ and this is perhaps particularly true in relation to cats rather than dogs. ${ }^{21}$ An incidence-based case control study of early RA suggested that prior blood transfusion might be a risk factor, ${ }^{22}$ with the transfusion often happening several years previously. Subjects with new onset arthritis are no more likely to report immediately preceding infection than the general population, ${ }^{23}$ but long latency from infection to disease onset might explain such a negative finding.

* This article was first published in The Journal of Rheumatology 2003;30:425-9 and is reproduced with the permission of the Editor. 
Studies looking for specific infective triggers for RA have generally relied on serological methods to detect prior exposure or culture or molecular methods to detect the organism or its genetic material in blood or synovial tissue. These have usually been cross-sectional studies in subjects with established disease. The results of such studies need to be treated with caution. First, many such studies lack appropriate controls. Second, the disease itself or its treatment might increase the likelihood of infection. Third, the detection of an organism in synovium (even in viable, replicating form) is not necessarily indicative of an active role in pathogenesis: there is evidence that synovial tissue may nonspecifically trap bacteria and viruses,,$^{24} 25$ and others may enter the inflamed synovium because they are parasitic residents of cells entering the joint (such as Epstein-Barr virus in B cells).

A large number of candidate organisms, both bacterial and viral, have been investigated and these studies are reviewed below. Detection of a previously undescribed trigger would be a far greater scientific challenge. There are, however, several molecular approaches that have been used to search for novel organisms. For example, synovial tissue can be screened for non-eukaryotic enzyme activity such as reverse transcriptase or heavily conserved components of the bacterial genome (such as 16S ribosomal genes). Subtraction techniques can also be used to search for nonhuman nucleic acid sequences.

\section{BACTERIA}

Mycobacteria. Over 70 years ago the histological similarity between rheumatoid synovitis and tuberculosis led Forestier and others to speculate that RA may be a mycobacterial infection, and many forms of mycobacteria are known to be arthritogenic. ${ }^{26}$ This hypothesis has been revisited many times since then, with the focus switching to atypical mycobacteria. Studies have shown elevated antibodies to mycobacterial heat shock proteins in sera ${ }^{27}$ of patients with RA, suggesting the possibility of a cross-reactive epitope. Yet this has not been a consistent finding. ${ }^{28}$ Further, extensive experimental studies have failed to show any evidence of mycobacterial infection by culture and/or molecular techniques, and trials of antimycobacterial chemotherapy have failed to produce consistent improvement in disease. ${ }^{29-31}$

Mycoplasmas. Mycoplasmas cause arthritis in some animal species that can be erosive, are associated with rheumatoid factor, and can last for at least a year. Mycoplasmas also cause a destructive arthritis in subjects with primary antibody deficiency. Numerous culture and polymerase chain reaction (PCR) based studies in both blood and synovium have been performed to look for evidence of infection by a variety of Mycoplasma species in human RA. Early studies are difficult to interpret, as until recently mycoplasmas were common unrecognized contaminants in many tissue culture systems. Most, but not all, recent studies report an increased frequency of Mycoplasma infection in RA compared to controls, but a similar prevalence for infection is also reported in other chronic inflammatory rheumatic diseases. ${ }^{32-35}$ The prevalence of infection in these studies is usually in the range 5-30\%. These data do not provide strong support for any obligate role for Mycoplasma in RA. Clinical trials that demonstrate a partial response to tetracycline treatment in RA may not support a role for Mycoplasma, as the former might be due to the anticytokine action or the inactivation of metalloproteinases by this class of antibiotics. ${ }^{36}$

Other bacteria. Ebringer has developed the hypothesis that Proteus mirabilis may trigger RA, based on serological studies and sequence similarity between a Proteus protein and the HLA-DRBl shared epitope. ${ }^{37}$ No convincing evidence has yet been presented, however, to show a link between persistent carriage of Proteus and RA. ${ }^{38}$
Carson [Albani], et al ${ }^{39}$ suggested that Escherichia coli heat shock protein dnaJ displayed the QKRAA amino acid sequence present in the HLA-DRBI shared epitope. Indeed, synovial cells from patients with early RA exhibited a marked response to the antigen, suggesting a cross-reactivity between that and activated $\mathrm{T}$ cells. Using combinatorial library techniques the same group demonstrated that IgG monoclonal anti-DNA antibody in a patient with RA showed homology with antibodies resulting from staphylococcal and Hemophilus infection. ${ }^{40}$

Several studies have used PCR based techniques to look for heavily conserved sequences of bacterial DNA in synovial samples from a variety of rheumatic diseases. DNA from a number of bacterial species have been detected in synovial fluid, although no consistent relationship between organism and disease is apparent from these studies, ${ }^{24}{ }^{41}$ except in cases of septic arthritis or post-chlamydial reactive arthritis. DNA from a wide variety of organisms, including Hemophilus, Bordetella, and Acinetobacter were isolated from synovial fluid from patients with RA. This is perhaps most consistent with inflamed synovium acting as a nonspecific trap for bacterial fragments (which might potentially play a role in disease perpetuation).

\section{VIRUSES}

Parvovirus. Parvovirus B19 infection is undoubtedly associated with short-lived arthropathy, with clinical similarities to RA. There is also some evidence to suggest that a chronic rheumatoid pattern arthritis can develop following the acute illness. However, serological evidence of human parvovirus infection was very infrequent in a large cohort of patients with very recent onset of arthritis, ${ }^{42}$ and persistence of Parvovirus DNA in synovium cannot be reliably linked to RA. ${ }^{43}$

Epstein-Barr virus. Epstein-Barr virus (EBV) is a potent stimulator of polyclonal B cell proliferation, and can induce the proliferation of autoantibody-producing B cells, including those producing rheumatoid factors. Serological studies from the 1970s also suggested that autoantibodies found in patients with RA might cross-react with EBV nuclear antigen. Sequence similarity has also been described between an EBV glycoprotein and the shared epitope. Serological and molecular evidence has been produced revealing coexistence of EBV infection and RA, but these studies are hard to interpret because of the high seroprevalence of EBV in most populations. ${ }^{44-46} \mathrm{EBV}$, however, has been frequently detected in the synovial tissues of RA patients (in contrast to its absence in osteoarthritis synovium). ${ }^{47}$ Further recent work has suggested that RA is associated with a decreased $\mathrm{T}$ cell response to EBV glycoprotein 110. This latter protein is important in the control of the viral replication, suggesting that RA is associated with persistence of EBV infection. ${ }^{48}$

Retroviruses. Caprine arthritis-encephalitis virus (CAE) infection in goats is characterized by adult onset chronic progressive arthritis with bursitis, tenosynovitis, and extraarticular involvement. The causative retrovirus, of the Lentivirus type, infects cells of the monocyte/macrophage lineage, although only a minority of synovial macrophages contain virus. ${ }^{49}$ HTLV-1 infection has been associated with chronic arthritis, particularly in Japanese subjects. ${ }^{50}$ The site of infection in HTLV-1 infection is the synovial fibroblast, which becomes transformed in a tumor-like fashion. HTLV-1 and CAE virus are not associated with RA, ${ }^{51}$ but these observations have led to a search for other retroviruses in RA, particularly as retrovirus-like particles have been observed in RA synovium by electron microscopy. A novel retrovirus, human retrovirus-5 (HRV-5), was first isolated from salivary gland. Subsequent PCR studies have revealed HRV-5 proviral DNA in $53 \%$ of RA synovial samples, and in $10 \%$ of peripheral 
blood samples from patients with RA. The virus was found in a similar proportion of peripheral blood samples from patients with systemic lupus erythematosus, but not in blood or tissue from other rheumatic diseases..$^{52}$

Other unknown viruses. A number of studies have used DNA subtraction technology to look for genes that are expressed in blood or tissues in RA, but not in health or in other disease states. These studies have, to date, failed to identify any sequences suggestive of novel pathogens, and usually identify genes encoding proteins involved in inflammation. ${ }^{53-55}$

What can be concluded from the studies reviewed above? It is clear that no overwhelming evidence exists to link any single known infectious agent with RA, although some candidate organisms seem particularly worthy of closer study, such as mycoplasmas and HRV-5, and the search for novel organisms needs to continue. However, future studies will produce more valid results only if greater rigor is applied to experimental design: prospective, inception based cohort studies are preferable to retrospective studies (although undeniably more expensive), and great care must be taken with choice of controls. Studies need to be designed to examine specific models of interaction between RA and infection, addressing variables such as attack rate, delay in onset, and persistence of infection. Progress is most likely to be made by close collaboration between epidemiologists and molecular microbiologists. Finally, the need for further study should not close our eyes to the possibility that RA is unrelated to infection.

\section{Authors' affiliations}

S M Carty, Rheumatology Department, University Hospital of Wales, Cardiff, Wales, UK

N Snowden, Department of Rheumatology, North Manchester General Hospital, Manchester, UK

A J Silman, ARC Epidemiology Unit, University of Manchester, Manchester, UK

Correspondence to: Professor A J Silman, ARC Epidemiology Unit, University of Manchester, Manchester, M13 9PT, UK; alan.silman@man.ac.uk

\section{REFERENCES}

1 Silman AJ, MacGregor AJ, Thomson W, et al. Twin concordance rates for rheumatoid arthritis: results from a nationwide study. $\mathrm{Br} J$ Rheumatol 1993;32:903-7.

2 Bellamy N, Duffy D, Martin N, Mathews J. Rheumatoid arthritis in twins: a study of aetiopathogenesis based on the Australian twin registry. Ann Rheum Dis 1992;51:588-93.

3 Buchanan WW, Boyle JA, Greig R, et al. Occurrence of autoantibodies in healthy twins. Clin Exp Immunol 1967;2:803-11.

4 Rowe DS, Boyle JA, Buchanan WW. Plasma immunoglobulin concentrations in twins. Clin Exp Immunol 1968;3:233-44.

5 Dalakos TG, MacSween RNM, Whaley K, et al. Conjugal prevalence of rheumatoid arthritis, rheumatoid factor and other autoantibodies in rheumatoid arthritis. Clin Exp Immunol 1968;3:761-69.

6 Söderlin MK, Kautiainen H, Puolakkainen M, et al. Infections preceding early arthritis in southern Sweden: a prospective population-based study J Rheumatol 2003;30:459-64.

7 Taylor-Robinson D, Keat A. Septic and aseptic arthritis: a continuum? Ballieres Best Clin Pract Res Clin Rheumatol 1999;13:179-92.

8 Buchanan WW. Rheumatoid arthritis: another New World disease? Semin Arthritis Rheum 1994;23:289-94.

9 Rothschild BM, Woods RJ. Symmetrical erosive disease in Archaic Indians: the origin of rheumatoid arthritis in the New World? Semin Arthritis Rheum 1990; 19:278-84

10 Silman AJ. The changing face of rheumatoid arthritis: why the decline in incidence? Arthritis Rheum 2002;46:579-81.

11 Jacobsson LT, Hanson RL, Knowler WC, et al. Decreasing incidence and prevalence of rheumatoid arthritis in Pima Indians over a twenty-five-year period. Arthritis Rheum 1994;37:1158-65.

12 Doran MF, Pond GR, Crowson CS, O'Fallon WM, Gabriel SE. Trends in incidence and mortality in rheumatoid arthritis in Rochester, Minnesota, over a forty-year period. Arthritis Rheum 2002;46:625-31.

13 Shichikawa K, Inove K, Hirota S, et al. Changes in the incidence and prevalence of rheumatoid arthritis in Kamitonda, Wakayama, Japan, 19651996. Ann Rheum Dis 1999;58:751-6.
14 Bankhead C, Silman A, Barrett B, Scott D, Symmons D. Incidence of rheumatoid arthritis is not related to indicators of socioeconomic deprivation. J Rheumatol 1996;23:2039-42.

15 Steere AC, Malawista SE, Snydman DR, et al. Lyme arthritis: an epidemic of oligoarticular arthritis in children and adults in three Connecticut communities. Arthritis Rheum 1977;20:7-17.

16 Silman A, Harrison B, Barrett E, Symmons D. The existence of geographic clusters of cases of inflammatory polyarthritis in a primary care based register. Ann Rheum Dis 2000;59:152-4.

17 Silman AJ, Bankhead C, Rowlingson B, Brennan P, Symmons D, Gatrell A. Do new cases of rheumatoid arthritis cluster in time or in space? Int J Epidemiol 1997; 26:628-34.

18 Chen E, Cobb S. Family structure in relation to health and disease. J Chron Dis 1960;12:544-67.

19 Spector TD, Silman A. Sibship size does not increase the risk of developing RA. Br J Rheumatol 1992;31:763-6.

20 Gottlieb NL, Ditchek N, Poiley J, Kiem IM. Pets and rheumatoid arthritis. An epidemiologic survey. Arthritis Rheum 1974;17:229-34.

21 Bond C, Cleland LG. Rheumatoid arthritis: are pets implicated in its etiology? Semin Arthritis Rheum 1996;25:308-17.

22 Symmons DPM, Bankhead CR, Harrison BJ, et al. Blood transfusion, smoking, and obesity as risk factors for the development of rheumatoid arthritis: results from a primary care-based incident case-control study in Norfolk, England. Arthritis Rheum 1997;40:1955-61.

23 Vandenbroucke JP, Kraaks R, Valkenburg HA. Frequency of infection among rheumatoid arthritis patients before and after disease onset. Arthritis Rheum 1987;30:810-3.

24 Wilkinson NZ, Kingsley GH, Jones HW, Sieper J, Braun J, Ward ME. The detection of DNA from a range of bacterial species in the joints of patients with a variety of arthritides using a nested, broad-range polymerase chain reaction. Rheumatology Oxford 1999;38:260-6.

25 Stahl HD, Hubner B, Seidl B, et al. Detection of multiple viral DNA species in synovial tissue and fluid of patients with early arthritis. Ann Rheum Dis 2000;59:342-7.

26 Rook GA, Lydyard PM, Stanford JL. Reappraisal of the evidence that rheumatoid arthritis and several other idiopathic diseases are slow bacterial infections. Ann Rheum Dis 1993;52(Suppl 1):S30-8.

27 Bahr GM, Rook GAW, Al-Saffar M, van Embden J, Stanford JL, Behbehani K. Antibody levels to mycobacteria in relation to HLA type: evidence for nonHLA-linked high levels of antibody to the $65 \mathrm{kD}$ heat shock protein of $M$. bovis in rheumatoid arthritis. Clin Exp Immunol 1988;74:211-5.

28 Worthington J, Rigby AS, MacGregor AJ, Silman AJ, Carthy D, Ollier WER. Lack of association of increased antibody levels to mycobacterial hsp65 with rheumatoid arthritis: results from a study of disease discordant twin pairs. Ann Rheum Dis 1993;52:542-4.

29 Pras E, Schumacher HR, Kasten DL, Wilder RL. Lack of evidence of mycobacteria in synovial tissue from patients with rheumatoid arthritis. Arthritis Rheum 1996;39:2080-1.

30 Borg AA, Davis MJ, Fowler PD, Shadforth MF, Dawes PT. Rifampicin in early rheumatoid arthritis. Scand J Rheumatol 1993;22:39-42.

31 van der Heijden I, Willbrink B, Schouls LM, van Embden JD, Breedveld FC, Tak PP. Detection of mycobacteria in joint samples from patients with arthritis using a genus-specific polymerase chain reaction and sequence analysis. Rheumatology Oxford 1999;38:547-53.

32 Schaeverbeke T, Gilroy CB, Bebear C, et al. Detection of Mycoplasma fermentans, but not $M$. penetrans, by PCR assays in synovial samples from patients with RA and other rheumatic disorders. J Clin Pathol 1996;49:824-8.

33 Schaeverbeke T, Renaudin H, Clerk M, et al. Systematic detection of mycoplasmas by culture and PCR in 209 synovial fluid samples. $\mathrm{Br} J$ Rheumatol 1997;36:310-4.

34 Haier J, Nasralla M, Franco AR, Nicolson GL. Detection of mycoplasma infections in blood of patients with rheumatoid arthritis. Rheumatology Oxford 1999;38:504-9.

35 Hoffman RW, O'Sullivan FX, Schafermyer KR, et al. Mycoplasma infection and rheumatoid arthritis. Arthritis Rheum 1997:40:1219-28.

36 Tilley BC, Alarcon GC, Heyse SP, et al. Minocycline in RA: a 48 week doubleblind placebo-controlled trial. Ann Intern Med 1995;122:81-9.

37 Subair $\mathbf{H}$, Tiwana $\mathrm{H}$, Fielder $M$, et al. Elevation in anti-Proteus antibodies in patients with rheumatoid arthritis from Bermuda and England. J Rheumatol 1995;22:1825-8

38 Gaston JSH. Proteus - Is it a likely aetiological factor in chronic polyarthritis? Ann Rheum Dis 1995;54:157-8.

39 Albani S, Keystone EC, Nelson JL, et al. Positive selection in autoimmunity: abnormal immune responses to a bacterial dna antigenic determinant in patients with early rheumatoid arthritis. Nature Medicine 1995;1:448-52.

40 Chukwuocha RU, Zhang B, Lai CJ, et al. Isolation of an IGG monoclonal antidnaJ antibody from an immunoglobulin combinatorial library from a patient with rheumatoid arthritis. J Rheumatol 1999;26:1439-45.

41 van der Heijden IM, Wilbrink B, Tchetverikov I, et al. Presence of bacterial DNA and bacterial peptidoglycans in joints of patients with RA and other arthritides. Arthritis Rheum 2000;43:593-8.

42 Harrison B, Silman A, Barrett E, Symmons D. Low frequency of Parvovirus infection in a population-based cohort of patients with early inflammatory polyarthritis. Ann Rheum Dis 1998;57:375-7.

43 Soderlund M, von Essen R, Haapasaari J, Kiistala U, Kiviluoto O, Hedman K. Persistence of parvovirus B19 DNA in synovial membranes of young patients with and without chronic arthropathy. Lancet 1997;349:1063-6.

44 Saal J, Krimmel M, Steidle M, et al. Synovial Epstein-Barr virus infection increases the risk of rheumatoid arthritis in individuals with the shared HLA DR4 epitope. Arthritis Rheum 1999;42:1485-96. 
45 Takei M, Mitamura K, Fujiwara S, et al. Detection of EBV-encoded small RNA 1 and LMP 1 in synovial lining cells from RA patients. Int Immunol 1997:9:739-43.

46 Niedobitek G, Lisner R, Swoboda B, et al. Lack of evidence for involvement of EBV infection of synovial membranes in the pathogenesis of RA. Arthritis Rheum 2000;43:1485-96.

47 Takeda T, Mizugaki Y, Matsubara L, Imai S, Koike T, Takada K. Lytic EpsteinBarr virus infection in the synovial tissue of patients with rheumatoid arthritis. Arthritis Rheum 2000:43:1218-25.

48 Toussirot E, Wendling D, Tiberghien P, Luka J, Roudier J. Decreased T cell precursor frequencies to Epstein-Barr virus glycoprotein gp 10 in periphera blood correlate with disease activity and severity in patients with rheumatoid arthritis. Ann Rheum Dis 2000;59:533-8.

49 Michaels FH, Banks KL, Reitz MS Jr. Lessons from caprine and ovine retrovirus infections. Rheum Dis Clin North Am 1991;17:5-23.
50 Hasunuma T, Sumida T, Nishioka K. Human T cell leukemia virus type-I and rheumatoid arthritis. Int Rev Immunol 1998;17:291-307.

51 Nelson PN, Bowman SJ, Hay FC, Lanchbury JS, Panayi GS, Lever AM Absence of exogenous retroviruses in Felty's syndrome. $\mathrm{Br} J$ Rheumatol 1995:34:185-7.

52 Griffiths DJ, Cooke SP, Herve C, et al. Detection of HRV5 in patients with arthritis and SLE. Arthritis Rheum 1999;42:448-54

53 Justen HP, Gruenwald E, Totke G, et al. Differential gene expression in synovium of RA and OA. Mol Cell Biol Res Commun 2000;3:165-72.

54 Stuhlmuller B, Ungethum U, Scholze S, et al. Identification of known and novel genes in activated monocytes from patients with RA. Arthritis Rheum 2000;43:775-90

55 Seki T, Selby J, Haupl T, Winchester R. Use of differential subtraction method to identify genes that characterise the phenotype of cultured RA synoviocytes. Arthritis Rheum 1998;41:1356-64. 